\title{
Orthodontic Treatment Need in 11-13 Years Old Shoolchildren in Republika Srpska
}

\author{
Mirjana Umićević Davidović, Marijana Arapović Savić, Adriana Arbutina \\ Department of Orthodontics, Study Program Dentistry, Faculty of Medicine, University of Banja Luka, Banja Luka, \\ Bosnia and Herzegovina
}

\begin{abstract}
SUMMARY
Introduction Need for orthodontic treatment is determined by the severity of specific malocclusion. Orthodontic indices are used to objectively present treatment needs. The most commonly used is the Index of Orthodontic Treatment Need (IOTN). The aim of this study was to determine the need for orthodontic therapy in 11 to 13 years old schoolchildren in Republika Srpska.

Material and Methods 1377 patients, 11 to 13 years old, were included in this study. The examinations were performed in elementary schools, using daylight, flat mirror and two-dimensional orthodontic caliper. Patients were ranked into 5 grades according to the Dental Health Component (DHC) and graded on a scale 1 to 10 for the Aesthetic Component (AC) of the IOTN index.

Results According to the Dental Health Component (DHC), 79.23\% of patients needed orthodontic treatment. Little and borderline orthodontic need was present in $27.74 \%$ and $24.83 \%$ children, respectively, while severe need was present in $19.98 \%$ and $6.68 \%$ respectively. $20.77 \%$ of subjects did not need orthodontic treatment. In regards to the Aesthetic Component (AC) (face appearance related to orthodontic need) little or no treatment was needed in $91.42 \%$ of subjects while $6.42 \%$ were borderline and $2.16 \%$ of subjects had severe relation between orthodontic need and facial appearance. Conclusion Due to the wide presence of orthodontic irregularities in schoolchildren 11-13 years old in Republika Srpska, it is important to introduce orthodontic indices in clinical practice in order to determine orthodontic treatment needs. Keywords: IOTN; orthodontic index; need for orthodontic treatment
\end{abstract}

\section{INTRODUCTION}

The aim of modern orthodontics is to enhance patient's life through improvements of functional occlusion and dentofacial aesthetics as well as to decrease psychological discomfort and increase self-confidence. Individual's needs and requests for orthodontic treatment differ according to the cultural and social environment. Urban environment and higher income are correlated with requests for orthodontic treatment since pleasant look enables higher social status [1-4].

In order to objectify need for orthodontic treatment, various methods are used to assess the severity and frequency of irregularities, both in individual cases and epidemiological studies. Malocclusions can be assessed using qualitative or quantitative methods [5, 6]. Qualitative methods are descriptive and do not provide information about the need for orthodontic treatment but mostly describe and classify irregularities. For quantitative measurements and recording of malocclusions, orthodontic indices have become more popular in the recent years. They can provide balanced interpretation and application of different criteria $[7,8,9]$. The best-known and most widely used index is the Index of Orthodontic Treatment Need (IOTN), that has been introduced in 1992 in Great Britain. The IOTN comprises two components: the Dental Health Component (DHC) and the Aesthetic Component
(AC) [10]. DHC is clinical component of dental health of IOTN index. Patients are grouped into five different grades according to the severity of orthodontic irregularity with every grade precisely defined $[10,11]$. AC is based on Evans' and Shaw's standard aesthetic scale (Standardized Continuum of Aesthetic Need - SCAN). It comprises illustrated scale with ten points (groups) and represents subjective perception of dental aesthetics [10,12].

The aim of this study was to determine the need for orthodontic therapy in 11 to 13 years old schoolchildren in Republika Srpska.

\section{MATERIAL AND METHODS}

The representative sample of 11- to 13-year-old children from schools in Republika Srpska was included in this study. The sample was chosen according to the data of Ministry of Education and Culture of Republika Srpska for schoolchildren of these ages in all municipalities. From all children, two staged stratified cluster sample that involved 1377 children 11- to 13-year-old was selected. Research included municipalities of Republika Srpska: Banja Luka, Bijeljina, Doboj, Istocno Sarajevo and Trebinje. Within each region random classes were included in the study.

Clinical examination was performed at school's premises, using daylight, flat mirror and two-dimensional 
orthodontic caliper. First part was related to the Dental Health Component (DHC) and second part to the Aesthetic Component (AC) of the IOTN index.

According to the health part of the index, occlusal anomalies were grouped into five grades according to the effect they have on oral health. The biggest effect on oral health had crowding, deep bite, crossbite, distal bite and missing teeth. Based on clinical examination subjects were categorized into one of five groups: DHC 1 - no need for treatment; DHC 2 - little need for treatment; DHC 3 - borderline need for treatment; DHC 4 - great need for treatment; DHC 5 - severe need for treatment.

Second part of examination included grading teeth composition in a smile compared to the reference scale of 10 standard front face photographs. Comparison was done based on teeth composition not just similarity with the photo. This part of research actively involved patients as they rated the appearance of their teeth. These grades were grouped into three categories based on the need for orthodontic therapy in relation to this component of the index: grades 1-4 - little or no need; 5-7 - borderline; 8-10 - great need for therapy.

In order to achieve required statistical strength the sample consisted of 1377 pupils. Based on the aforementioned, a weight for each region was established. Weight is a coefficient assigned to every observed participant in the research, in order to obtain results valid for the whole population. Based on the exact number of 11- to 13-yearold schoolchildren provided by the Ministry of Education and Culture of Republika Srpska the representative sample and a weight were formed based on well-defined attributes. For this research, the weight was determined as the ratio of the number of examined children in a school class within each region and total number of children that attended all school classes in a given region. Based on this way defined weight, results were presented for the whole population. All results were statistically significant.

Qualitative data were presented through frequency and percentage, while statistical strength was determined by standard error for proportions and 95\% confidence interval. Quantitative data were presented by basic descriptive statistic measures (mean value, standard error, $95 \%$ confidence interval, median value, first and third quartile as well as minimum and maximum).

\section{RESULTS}

According to the severity of orthodontic irregularity and need for orthodontic treatment all tested subjects were classified in five grades of DHC. The number of subjects per grade according to this component is presented in Table 1. The highest number of children was classified in group $2(27.74 \%)$ and the lowest was in group $5(6.39 \%)$.

According to the Aesthetic Component (AC), it was determined that $91.42 \%$ of patients had no or little need, $6.42 \%$ of patients showed borderline need while $2.16 \%$ of patients showed great need for orthodontic treatment (Table 2).
Table 1. Number of patients according to the Dental Health Component (DHC) grading system

Tabela 1. Učestalost ispitanika po grupama prema zdravstvenoj komponenti (DHC)

\begin{tabular}{|c|c|c|c|c|c|}
\hline \multirow{2}{*}{ DHC } & \multirow{2}{*}{$\mathbf{N}$} & \multirow{2}{*}{$\%$} & \multirow{2}{*}{ SE } & \multicolumn{2}{|c|}{ 95\% CI } \\
\cline { 5 - 6 } & & & & Lower & Upper \\
\hline DHC 1 & 2442 & 20.77 & 0.0238 & 16.11 & 25.43 \\
\hline DHC 2 & 3262 & 27.74 & 0.0229 & 23.25 & 32.23 \\
\hline DHC 3 & 2919 & 24.83 & 0.0236 & 20.21 & 29.46 \\
\hline DHC 4 & 2349 & 19.98 & 0.0244 & 15.20 & 24.76 \\
\hline DHC 5 & 785 & 6.68 & 0.0249 & 1.79 & 11.56 \\
\hline $\begin{array}{c}\text { Total } \\
\text { Ukupno }\end{array}$ & 11756 & 100.00 & & & \\
\hline
\end{tabular}

$\mathrm{N}$ - number of subjects; $\mathrm{SE}$ - standard error; $\mathrm{Cl}$ - confidence interval

$\mathrm{N}$ - broj ispitanika; $\mathrm{SE}$ - standardna greška; $\mathrm{Cl}$ - interval poverenja

Table 2. Need for orthodontic treatment according to the Aesthetic Component (AC) graded by the examiner

Tabela 2. Potreba za ortodontskim lečenjem prema estetskoj oceni (AC) ispitivača

\begin{tabular}{|c|c|c|c|c|c|}
\hline \multirow{2}{*}{ AC } & \multirow{2}{*}{$\mathbf{N}$} & \multirow{2}{*}{$\%$} & \multirow{2}{*}{ SE } & \multicolumn{2}{|c|}{$95 \%$ Cl } \\
\cline { 5 - 6 } & & & & Lower & Upper \\
\hline AC 1-4 & 10747 & 91.42 & 0.0079 & 89.86 & 92.97 \\
\hline AC 5-7 & 755 & 6.42 & 0.0256 & 1.41 & 11.43 \\
\hline AC 8-10 & 254 & 2.16 & 0.0246 & 0.00 & 6.98 \\
\hline $\begin{array}{c}\text { Total } \\
\text { Ukupno }\end{array}$ & 11756 & 100.00 & & & \\
\hline
\end{tabular}

Table 3. Need for orthodontic treatment according to the Aesthetic Component $(\mathrm{AC})$ graded by patients

Tabela 3. Potreba za ortodontskim lečenjem prema estetskoj oceni (AC) ispitanika

\begin{tabular}{|c|c|c|c|c|c|}
\hline \multirow{2}{*}{ AC } & \multirow{2}{*}{$\mathbf{N}$} & \multirow{2}{*}{$\%$} & \multirow{2}{*}{ SE } & \multicolumn{2}{|c|}{$95 \% \mathrm{Cl}$} \\
\cline { 5 - 6 } & & & & Lower & Upper \\
\hline AC 1-4 & 10925 & 92.93 & 0.0072 & 91.52 & 94.34 \\
\hline AC 5-7 & 714 & 6.07 & 0.0256 & 1.05 & 11.09 \\
\hline AC 8-10 & 118 & 1.00 & 0.0222 & 0.00 & 5.36 \\
\hline $\begin{array}{c}\text { Total } \\
\text { Ukupno }\end{array}$ & 11756 & 100.00 & & & \\
\hline
\end{tabular}

Grades assigned by patients followed the grades assigned by examiner, but they were less critical. According to the Aesthetic Component (AC) graded by patients, there was little or no need present in $92.93 \%$ of patients, borderline need in $6.07 \%$ and great need for orthodontic treatment in $1.00 \%$ of children (Table 3 ).

Aesthetic grade assigned by patients was on average higher than the one graded by the examiner in children that were classified in grades 1 and 2, while in other grades grade given by the exminer was on average higher then given by patients (Table 4 ).

\section{DISCUSSION}

The Dental Health Component (DHC) of the IOTN index is the main indicator of the need for orthodontic treatment. By analyzing this component one can obtain data about distribution of malocclusions, as well as the severity of malocclusion. Orthodontic irregularities are widely distributed so the biggest importance is given to the DHC 
Table 4. Average Aesthetic Compomenet (AC) determined by the exminer and patient compared to Dental Health component (DHC) Tabela 4. Prosečne estetske ocene (AC) ispitivača i ispitanika prema zdravstvenoj komponenti (DHC)

\begin{tabular}{|c|c|c|c|c|c|c|c|c|c|c|}
\hline DHC & $A C$ & $\overline{\mathbf{x}}$ & SE & Min & $Q_{1}$ & $\mathbf{Q}_{2}$ & $\mathbf{Q}_{3}$ & MAX & $95 \%$ & $6 \mathrm{Cl}$ \\
\hline \multirow{2}{*}{$\mathrm{DHC} 1$} & $\begin{array}{l}\text { Examiner } \\
\text { Ispitivač }\end{array}$ & 1.22 & 0.0084 & 1 & 1 & 1 & 1 & 2 & 1.20 & 1.23 \\
\hline & \begin{tabular}{|l|} 
Patient \\
Ispitanik
\end{tabular} & 1.57 & 0.0148 & 1 & 1 & 1 & 2 & 4 & 1.55 & 1.60 \\
\hline \multirow{2}{*}{ DHC 2} & $\begin{array}{l}\text { Examiner } \\
\text { Ispitivač }\end{array}$ & 2.34 & 0.0143 & 1 & 2 & 2 & 3 & 5 & 2.31 & 2.37 \\
\hline & \begin{tabular}{|l|} 
Patient \\
Ispitanik \\
\end{tabular} & 2.37 & 0.0175 & 1 & 2 & 2 & 3 & 6 & 2.34 & 2.41 \\
\hline \multirow{2}{*}{$\mathrm{DHC} 3$} & $\begin{array}{l}\text { Examiner } \\
\text { Ispitivač }\end{array}$ & 2.98 & 0.0181 & 1 & 2 & 3 & 3 & 7 & 2.94 & 3.01 \\
\hline & \begin{tabular}{|l|} 
Patient \\
Ispitanik \\
\end{tabular} & 2.72 & 0.0212 & 1 & 2 & 3 & 3 & 9 & 2.68 & 2.76 \\
\hline \multirow{2}{*}{ DHC 4} & \begin{tabular}{|l|} 
Examiner \\
Ispitivač
\end{tabular} & 3.69 & 0.0339 & 1 & 3 & 3 & 4 & 8 & 3.62 & 3.75 \\
\hline & $\begin{array}{l}\text { Patient } \\
\text { Ispitanik }\end{array}$ & 3.22 & 0.0310 & 1 & 2 & 3 & 4 & 9 & 3.16 & 3.28 \\
\hline \multirow{2}{*}{ DHC 5} & $\begin{array}{l}\text { Examiner } \\
\text { Ispitivač }\end{array}$ & 4.59 & 0.0931 & 1 & 3 & 4 & 6 & 10 & 4.41 & 4.77 \\
\hline & $\begin{array}{l}\text { Patient } \\
\text { Ispitanik }\end{array}$ & 3.71 & 0.0693 & 1 & 2 & 3 & 5 & 10 & 3.57 & 3.84 \\
\hline
\end{tabular}

$\bar{X}$ - mean value; $S E$ - standard error; Min - Minimum value; $Q_{1}$ - first quartile; $\mathrm{Q}_{2}$ - median; $\mathrm{Q}_{3}$ - third quartile

$\bar{X}$ - aritmetička sredina; SE - standardna greška; Min - najmanja vrednost;

$\mathrm{Q}_{1}$ - prvi kvartil; $\mathrm{Q}_{2}$ - medijana; $\mathrm{Q}_{3}$ - treći kvartil

grades 4 and 5 where there is a need for orthodontic treatment in order to prevent damaging orofacial health. In the current research, $26.66 \%$ of patients were determined as grades 4 and 5 indicating that in total $>3000$ of 11 - to 13-year-old children in Republika Srpska need orthodontic treatment. Similar results were obtained in the study of Perillo et al. [13], who examined 12-year-olds in Italy and found the DHC grade 4 and 5 in $27.3 \%$ of children. Souames et al. [14] in France among 12-year-olds found 21.8\% and Manzanera et al. [15] in Spain for children ages 9 to 12 found $21 \%$ of them needed orthodontic treatment. In Germany Tausche et al. [16] came to similar results $(21.5 \%)$, but in younger children, age 6 to 8 years.

In other research conducted in Europe, these values were somewhat higher when compared to the current study. In Great Britain Brook and Shaw [10] found that $32.7 \%$ of 11- and 12-year- olds needed orthodontic treatment. Similar results were presented by Burden [17] in Northern Ireland with 36\%, and Josefsson et al. [18] in Sweden with $37 \%$ of 12 - and 13-year-olds that needed orthodontic correction of malocclusion.

Various authors outside of Europe performed similar research among children age 11 to 14 in Turkey, Japan and Iran. Uçüncü and Ertugay [19] in Turkey found that 38.8\% of children needed orthodontic treatment. Watanabe et al. [20] in Japan came to similar results (34.1\%), while in Iran Hedayati et al. [21] came to significantly lower values of $18.4 \%$. In Jordan and Malaysia researchers conducted research among 12- and 13-year-olds. Hamdan [22] reported that $31 \%$ of Jordan children needed orthodontic treatment, while Abdullah and Rock [23] selected 47.9\% of Malaysian patients in this category. Dias et al. [24] performed research in Brazil among 405 children age 9 to 12 and classified $34.2 \%$ of children in the DHC groups 4 and 5 .
Main role of the Aesthetic Component (AC) of the IOTN index is to determine the association between the face appearance and orthodontic irregularity. Manzanera et al. [15] graded 12-year-olds in Spain as follows: 1-4 little or no need for treatment $85.4 \%, 5-7$ borderline need $10.2 \%$ and $8-10$ great need for treatment in $4.4 \%$ of patients. Souames et al. [14] reported similar grades regarding aesthetics among children age 9 to 12 in France. They found grades 1-4 with little to no need for treatment in $75 \%$ of children; grades 5-7 with borderline need in $18 \%$ and $7 \%$ in grades $8-10$ with great need for orthodontic treatment.

In Italy, Nobile et al. [25] conducted research among children age 11 to 14 where they compared the AC grades by the examiner and by patients, similar to the current research. They came to the following results: grades 1-4 with little or no need examiners found in $77.8 \%$ and patients in $91.5 \%$ of cases, grades $5-7$ with borderline need in $13.6 \%$ by examiner and in $5.4 \%$ by patients and grades $8-10$ with great need for treatment in $8.6 \%$ by examiner and $3.2 \%$ by patients. Based on these results, they came to conclusion that professional dental opinion was significantly more critical than patients' opinion. Linder-Arson [11] came to the same conclusion in Sweden as well as Abdullah and Rock [23] among subjects in Malaysia.

Tauche et al. [16] in their research of children age 6 to 8 in Germany came to significantly different results. Grades 1-4 with little or no need for treatment were found in 34\%, grades 5-7 with borderline need in $44.5 \%$ and grades 8-10 with great need for treatment in 21.5\% of patients. Holmes [26], Crowther et al. [27] and Souames et al. [14] suggested that AC should not be applied in children with mixed dentition as some "temporary" orthodontic irregularities may be corrected in time during the most pronounced growth period by eliminating bad habits (sucking thumbs, tongue pushing, mouth breathing). Due to these reasons there are high values for orthodontic treatment need when $\mathrm{AC}$ is applied in children with mixed dentition.

\section{CONCLUSION}

Orthodontic irregularities are common among children in Republika Srpska. More then one quarter of patients needed urgent orthodontic treatment in order to prevent further degradation of their orofacial system's health. Conducting periodic epidemiological studies and applying orthodontic indices is of great importance for planning and implementing prevention, as well as organizing dental health service.

\section{REFERENCES}

1. Proffit W, Fields HW, Sarver DM. Contemporary Orthodontics. 4th ed. St. Louis, Missouri, USA: Mosby Elsevier; 2007. p.16-22.

2. Tickle M, Kay EJ, Bearn D. Socio-economic status and orthodontic treatment need. Community Dent Oral Epidemiol. 1999; 27:413-8. [DOI: 10.1111/j.1600-0528.1999.tb02040.x] [PMID: 10600074] 
3. Dogan AA, Sari E, Ushun E. Comparison of orthodontic treatment need by professionals and parents with different socio-demographic characteristics. Eur J Orthodont. 2010; 32:672-6. [DOl: 10.1093/ejo/cjp161] [PMID: 20299423]

4. Paulo F, Paulo CN. Socio-enviromental factors associated with dental occlusion in adolescents. Am J Orthodont Dentofacial Orthop. 2006; 129:809-16. [DOI: 10.1016/j.ajodo.2004.10.016] [PMID: 16769500]

5. Jarinen S. Indexes for orthodontic treatment need. Am J Orthodont Dentofacial Orthop. 2001; 120:237-9. [DOl: 10.1067/mod.2001.114830] [PMID: 11552121]

6. Tang EZ, Wei SH. Recording and measuring malocclusions: a review of the literature. Am J Orthodont Dentofacial Orthop. 1993; 103:34451. [DOI: 10.1016/0889-5406(93)70015-G] [PMID: 8480700]

7. Shaw WC, Richmond S, O'Brien KD. Quality control in orthodontics: Indices of Treatment Need and treatment standards. Brit Dent J. 1991; 170:107-12. [DOl: 10.1038/sj.bdj.4807429] [PMID: 2007067]

8. Shaw WC, Richmond S, O'Brien KD. The use of occlusal indices: a European perspective. Am J Orthodont Dentofacial Orthop. 1995; 107:1-10. [DOI: 10.1016/S0889-5406(95)70151-6] [PMID: 7817954]

9. Jones CM, Woods K, O'Brien K, Winard C, Taylor GO. Index of Orthodontic Treatment Need, its use in a dental epidemiology survey calibration exercise. Community Dent Health. 1996; 13:208-10. [PMID: 9018884]

10. Brook PH, Shaw WC. The development of an index of orthodontic treatment priority, Eur J Orthodont. 1989; 11:309-20. [PMID: 2792220]

11. Lindrer-Arson S. Orthodontics in the Swedish public dental health system. Eur J Orthodont. 2007; 29:i124-7. [DOl: 10.1093/ejo/cjl078]

12. Evans MR, Shaw WC. Preliminary evaluation of an illustrated scale for rating dental attractiveness. Eur J Orthodont. 1987; 9:314-8. [DOI: 10.1093/ejo/9.1.314] [PMID: 3480231]

13. Perillo L, Masucci C, Ferro F, Apicella D, Bacceti T. Prevalence of orthodontic treatment need in southern Italian schoolchildren. Eur J Orthodont. 2010; 32:49-53. [DOI: 10.1093/ejo/cjp050] [PMID: 19706641]

14. Souames M, Bassigny Zenati N, Riordan PJ, Boy-Lefevre ML. Orthodontic treatment need in Franch schoolchildren: an epidemiological study using the Index of Orthodontic Treatment Need. Eur J Orthodont. 2006; 28:605-9. [DOI: 10.1093/ejo/cjl045] [PMID: 17095742]

15. Manzanera D, Montiel-Company JM, Almerich-Silla JM, Gaudia JL. Orthodontic treatment need in Spanish schoolchildren: an epidemiological study using the Index of Orthodontic Treatment Need. Eur J Orthodont. 2009; 31:180-3. [DOI: 10.1093/ejo/cjn089] [PMID: 19064676]
16. Tausche E, Luck O, Harzer W. Prevalence of malocclusions in the early mixed dentition and orthodontic treatment need. Eur J Orthodont. 2004; 26:237-44. [DOI: 10.1093/ejo/26.3.237] [PMID: 15222706]

17. Burden DJ. Need for orthodontic treatment in Northern Ireland. Community Dent Oral Epidemiol. 1995; 23:62-3.

[DOl: 10.1111/j.1600-0528.1995.tb00200.x] [PMID: 7774180]

18. Josefsson E, Bjerklin K, Lindsten R. Malocclusion frequency in Swedish and immigrant adolescents - influence of origin on orthodontic treatment need. Eur J Orthodont. 2007; 29:79-87. [DOl: 10.1093/ejo/cjl054] [PMID: 17290019]

19. Uçüncü N, Ertugay E. The use of the Index of Orthodontic Treatment need (IOTN) in school population and refered population. J Orthodont. 2001; 28:45-52. [DOl: 10.1093/ortho/28.1.45] [PMID: 11254803]

20. Watanabe A, Mohri T, Watanabe N, Watanabe Y, Miyazaki H, Saito I. Epidemiological investigation of malocclusion in Japan using the index of orthodontic treatment need (IOTN). Orthodont Waves. 2010; 69:39-43. [DOl: 10.1016/j.odw.2009.12.012]

21. Hedayati Z, Fattahi HR, Jahromi SB. The use of index of orthodontic treatment need in an Iranian population. J Indian Society Pedodont Prevent Dent. 2007; 25:10-4. [DOI: 10.4103/0970-4388.31982] [PMID: 17456960]

22. Hamdan AM. The relationship between patient, parent and clinician perceived need and normative orthodontic treatment need. Eur J Orthodont. 2004; 26:265-71. [DOI: 10.1093/ejo/26.3.265] [PMID: 15222710]

23. Abdullah MS, Rock WP. Assessment of orthodontic treatment need in 5,112 Malaysian children using the IOTN and DAI indices. Community Dent Health. 2001; 18:242-8. [PMID: 11789703]

24. Dias PF, Gleiser R. Orthodontic concerns of Brazilian children and their parents compared to the normative treatment need. J Oral Sci. 2010; 52:101-7. [DOI: 10.2334/josnusd.52.101] [PMID: 20339240]

25. Nobile C, Pavia M, Fortunato L, Angelillo I. Prevalence and factors related to malocclusion and orthodontic treatment need in children and adolescents in Italy. Eur J Public Health. 2007; 17:637-41. [DOl: 10.1093/eurpub/ckm016] [PMID: 17400542]

26. Holmes A. The subjective need and demand for orthodontic treatment. Brit J Orthodont. 1992; 19:287-97. [PMID: 1463704]

27. Crowther P, Harkness M, Herbison P. Orthodontic treatment need in 10-year-old Dunedin schoolchildren. New Zealand Dent J. 1997; 9:72-8. [PMID: 9323895] 


\title{
Potreba za ortodontskim lečenjem kod dece uzrasta od 11 do 13 godina u Republici Srpskoj
}

\author{
Mirjana Umićević Davidović, Marijana Arapović Savić, Adriana Arbutina \\ Katedra za ortopediju vilica, Studijski program Stomatologija, Medicinski fakultet, Univerzitet u Banjoj Luci, Banja Luka, \\ Bosna i Hercegovina
}

\begin{abstract}
KRATAK SADRŽAJ
Uvod Potreba za ortodontskom terapijom se procenjuje na osnovu težine određene malokluzije. Objektivizacija problema potrebe za ortodontskim lečenjem se analizira uvođenjem ortodontskih indeksa. Najpoznatiji takav indeks je indeks potrebe za ortodontskom terapijom (engl. Index of Orthodontic Treatment Need -IOTN). Cilj ovog rada je bio da se utvrdi potreba za ortodontskom terapijom kod dece uzrasta 11-13 godina u Republici Srpskoj.

Materijal i metode rada Pomoću IOTN kod 1.377 ispitanika uzrasta od 11 do 13 godina procenjivana je potreba za ortodontskim lečenjem. Pregledi su obavljeni u prostorijama osnovnih škola pri dnevnom svetlu i pomoću ravnog ogledala i dvokrakog ortodontskog šestara. Ispitanici su svrstani u pet grupa prema zdravstvenoj komponenti (DHC) i ocenjeni sa 10 ocena estetske komponente (AC) IOTN.

Rezultati Prema DHC, 79,23\% ispitanika imalo je potrebu za ortodontskim lečenjem. Mala i srednja potreba zabeležena je kod $27,74 \%$, odnosno $24,83 \%$ dece, dok je velika i veoma velika potreba utvrđena kod $19,98 \%$, odnosno $6,68 \%$ dece. Ispitanika kojima nije bila potrebna ortodontska terapija bilo je $20,77 \%$. U pogledu narušenosti izgleda ortodontskom nepravilnošću, ustanovljeno je da je prema AC malu ili nikakvu potrebu za terapijom imalo 91,42\% ispitanika, srednju potrebu 6,42\%, a veliku potrebu 2,16\% dece. Zaključak Zbog velike rasprostranjenosti ortodontskih nepravilnosti u Republici Srpskoj, veoma bi bilo značajno da se u kliničkoj praksi primenjuju ortodontski indeksi, kako bi se na osnovu takvih analiza mogli odrediti prioriteti u lečenju.

Ključne reči: IOTN; ortodontski indeks; potreba za ortodontskom terapijom
\end{abstract}

\section{UVOD}

Cilj savremene ortodoncije je unapređenje života pacijenta poboljšavanjem funkcionalne okluzije i dentofacijalnog estetskog izgleda, čime se utiče i na njegovo psihološko rasterećenje i samopouzdanje. Potreba i zahtev pojedinca za ortodontskom terapijom se razlikuje u različitim kulturnim i socijalnim krugovima. Gradska sredina i viši prihodi porodice su u korelaciji sa zahtevom za lečenje, jer prijatan izgled omogućava bolji društveni i socijalni status [1-4].

Da bi se problem potrebe za ortodontskim lečenjem objektivizovao, uvedene su različite metode za procenu težine i učestalosti određenih nepravilnosti, koje se mogu koristiti za pojedinačne slučajeve, ali i u svrhe epidemioloških istraživanja. Evidentiranje malokluzija može biti kvalitativno i kvantitativno $[5,6]$. Kvalitativne metode su deskriptivne i ne pružaju informaciju o potrebi za ortodontskom terapijom, već više opisuju i klasifikuju nepravilnosti u grupe. Za kvantitativna merenja i evidentiranja malokluzija u poslednje vreme se sve više koriste indeksi koji služe kao pokazatelji određenog stanja ili proporcionalni odnos koji se može izvesti kroz niz zapažanja. Korišćenje indeksa treba da osigura ujednačeno tumačenje i primenu kriterijuma [7, 8,9]. Najpoznatiji i najčešće korišćen je indeks potrebe za ortodontskim terapijom (engl. Index of Orthodontic Treatment Need - IOTN), koji se od 1992. godine prvenstveno koristi u Velikoj Britaniji. IOTN se sastoji od dve komponente: zdravstvene (engl. dental health component - DHC) i estetske (engl. aesthetic component - AC) [10]. DHC je klinička, odnosno komponenta dentalnog zdravlja IOTN. Pomoću ovog dela indeksa pacijenti se prema izraženosti ortodontske nepravilnosti svrstavaju u pet različitih grupa s tačno određenim graničnim vrednostima [10,11]. AC se zasniva na Evansovoj (Evans) i Šoovoj (Shaw) standardnoj estetskoj skali (engl. standardized continuum of aesthetic need - SCAN). Ona se sastoji od ilustrovane skale sa deset stepeni (grupa) i predstavlja estetski kriterijum subjektivnog doživljaja dentalne estetike $[10,12]$.

Cilj ovog rada je bio da se utvrdi potreba za ortodontskom terapijom kod dece uzrasta od 11 do 13 godina u Republici Srpskoj.

\section{MATERIJAL I METODE RADA}

Podaci u ovom istraživanju su prikupljeni na osnovu uzorka koji je kreiran tako da bude reprezentativan za svu decu od 11 do 13 godina koja pohađaju osnovne škole u Republici Srpskoj. Okvir uzorka činili su podaci Ministarstva prosvete i kulture Republike Srpske o učenicima ovog uzrasta osnovnih škola u svim opštinama Republike Srpske. Iz ovog okvira urađen je dvoetapni stratifikovani klaster uzorak, tako da je u istraživanje bilo uključeno 1.377 dece uzrasta 11-13 godina. Regije koje su zastupljene u ovom istraživanju, a koje obuhvataju sve opštine Republike Srpske, bile su Banja Luka, Bijeljina, Doboj, Istočno Sarajevo i Trebinje. Unutar svake regije nasumično su izabrani razredi u školama u kojima su pregledani svi učenici.

Klinički pregled je obavljan u prostorijama škola, pri dnevnom svetlu i pomoću ravnog stomatološkog ogledala i dvokrakog ortodontskog šestara. Prvi deo se odnosio na zdravstvenu komponentu (DHC), a drugi na estetsku komponentu (AC) IOTN.

Prema zdravstvenom delu indeksa, okluzalne anomalije su svrstane u pet kategorija prema uticaju koji imaju na oralno zdravlje. Smatra se da najveći uticaj na oralno zdravlje imaju teskoba, dubok zagrižaj, ukršten zagrižaj, distalni zagrižaj i nedostatak zuba, tako da se ocena daje na osnovu najtežeg kliničkog nalaza. Na osnovu kliničkog nalaza ispitanici su svrstani u jednu od pet grupa: DHC 1 - nema potrebe za lečenjem; DHC 2 - mala potreba za lečenjem; DHC 3 - srednja potreba za lečenjem; DHC 4 - velika potreba za lečenjem; DHC 5 - veoma velika potreba za lečenjem. 
Drugi deo pregleda sastojao se od ocenjivanja odnosa zuba pri osmehu poređenjem sa skalom od 10 standardnih fototografija lica spreda, pri čemu se ocenjivao izgled zuba, a ne sličnost s fotografijom. U ovom delu ispitivanja aktivno su učestvovali i svi ispitanici tako što su sami ocenjivali izgled svojih zuba. Ove ocene su grupisane u tri kategorije prema potrebi za ortodontskom terapijom u odnosu na ovu komponentu indeksa: ocena 1-4 - mala ili nikakva; ocena 5-7 - srednja; ocena 8-10 - velika potreba za terapijom.

Da bi se postigla dovoljna statistička snaga, u uzorak je uključeno 1.377 učenika. Na osnovu opisanog izbora kreirani su i ponderi unutar svake regije. Ponder je koeficijent koji se dodeljuje svakoj jedinici posmatranja, odnosno svakom ispitaniku u istraživanju, s ciljem dobijanja rezultata za čitavu populaciju, a ne samo za posmatrani uzorak. Na osnovu preciznih podataka Ministarstva prosvete i kulture o broju dece uzrasta 11-13 godina koja pohađaju osnovne škole u Republici Srpskoj, formiran je reprezentativan uzorak, a kasnije i ponder pomoću dobro definisanih obeležja koja određuju glavne karakterisitike ispitanika. U ovom istraživanju ponder je određen kao odnos broja ispitivane dece u pojedinom razredu škole unutar pojedine regije i ukupnog broja dece koja pohađaju sve razrede u svim školama unutar te regije. Na osnovu ovako definisanog pondera, u statističkoj analizi su rezultati prikazani za čitavu populaciju. Svi rezultati dobijeni na ovaj način su statistički značajni.

Kvalitativni podaci su predstavljeni kroz učestalost i procentualni udeo, a statistička snaga ovih rezultata je proverena ocenom standardne greške za proporcije i 95-procentni interval poverenja (95\% CI). Kvantitativni podaci su prikazani osnovnim pokazateljima deskriptivne statistike: aritmetička sredina $(\overline{\mathrm{X}})$, standardna greška (SE), 95\% CI, medijana (Med), prvi i treći kvartil, te najmanja vrednost (Min) i najveća vrednost (Max).

\section{REZULTATI}

Ispitanici su prema stepenu izraženosti ortodontske nepravilnosti i potrebi za ortodontskom terapijom svrstani u pet grupa DHC. Raspodela ispitanika po grupama prema ovoj komponenti prikazana je u tabeli 1. Najveći broj dece bio je u grupi 2 DHC $(27,74 \%)$, a najmanji u grupi $5(6,39 \%)$.

Prema AC, ustanovljeno je da je kod $91,42 \%$ ispitanika prisutna mala ili nikakva potreba, kod 6,42\% srednja, a kod 2,16\% velika i veoma velika potreba za ortodontskim lečenjem (Tabela 2).

Ocene ispitanika prate ocene ispitivača, ali su manje kritične. Prema AC ispitanika o potrebi za ortodontskom terapijom, ustanovljeno je da malu ili nikakvu potrebu imalo 92,93\%, srednju potrebu $6,07 \%$, a veliku i veoma veliku potrebu za terapijom $1,00 \%$ dece (Tabela 3).

Estetska ocena ispitanika je u proseku bila veća od ocene ispitivača kod dece koja su u grupama 1 i 2, dok je u ostalim grupama bila veća prosečna estetska ocena ispitivača (Tabela 4).

\section{DISKUSIJA}

Zdravstvena komponenta (DHC) IOTN je glavni pokazatelj potrebe za ortodontskom terapijom. Analizom ove komponente dobijaju se podaci o rasprostranjenosti malokluzija, kao i stepenu njihove izraženosti. Rasprostranjenost ortodontskih ne- pravilnosti je veoma velika, pa se najveći značaj pridaje 4. i 5. DHC grupi s velikom i veoma velikom potrebom za terapijom, kojima je lečenje neophodno da bi se zaustavilo narušavanje zdravlja celog stomatognatog sistema. U ovom istraživanju je utvrđeno da je 26,66\% ispitanika pripadalo ovim dvema grupama, što ukazuje na to da je kod više od 3.000 dece uzrasta od 11 do 13 godina u Republici Srpskoj neophodna ortodontska terapija. Ovi nalazi su najsličniji rezultatima do kojih su došli Perilo (Perillo) i saradnici [13] u svome istraživanju u Italiji među dvanaestogodišnjacima, pri čemu je ova vrednost bila $27,3 \%$. Nešto niže vrednosti $(21,8 \%)$ zabeležene su u istraživanju Suama (Souames) i saradnika [14] u Francuskoj takođe među dvanaestogodišnjacima, i Manzanere (Manzanera) i saradnika [15] u Španiji među decom uzrasta 9-12 godina (21\%). U Nemačkoj je Taušeova (Tausche) sa saradnicima [16] došla do sličnih rezultata $(21,5 \%)$, ali je istraživanje urađeno među mlađim ispitanicima uzrasta od šest do osam godina.

U drugim istraživanjima evropskih autora ove vrednosti su bile nešto veće nego u našem istraživanju. Tako su u Velikoj Britaniji Bruk (Brook) i Šo (Shaw) [10] ustanovili da 32,7\% jedanaestogodišnjaka i dvanaestogodišnjaka ima veliku ili veoma veliku potrebu za ortodontskim lečenjem. Slične rezultate su dobili i Burden (Burden) [17] u Severnoj Irskoj (36\%) i Jozefson (Josefsson) i saradnici [18] u Švedskoj (37\%), koji su istraživanje obavili među decom uzrasta od 12 i 13 godina.

Slične studije su izvodili i autori u zemljama van Evrope. Istraživanje među decom uzrasta od 11 do 14 godina su urađena u Turskoj, Japanu i Iranu. Učunku (Uçüncü) i Ertugaj (Ertugay) [19] u Turskoj su među 550 dece ovog uzrasta ustanovili da $38,8 \%$ njih ima veliku i veoma veliku potrebu za terapijom. Vatanabe (Watanabe) i saradnici [20] u Japanu došli su do sličnih rezultata $(34,1 \%)$, dok su u Iranu Hedajati (Hedayati) i saradnici [21] dobili značajno niže vrednosti za ovu grupu (18,4\%). U Jordanu i Maleziji su istraživači izveli istraživanje o potrebi za ortodontskom terapijom među decom uzrasta 12-13 godina. Hamdan (Hamdan) [22] je ustanovio da 31\% jordanske dece ovoga uzrasta ima veliku i veoma veliku potrebu za ortodontskom terapijom, dok su Abdulah (Abdullah) i Rok (Rock) [23] u ovu grupu svrstali 47,9\% malezijskih ispitanika. Dijas (Dias) i saradnici [24] su među 405 brazilske dece uzrasta 9-12 godina u 4. i 5. DHC grupu svrstali 34,2\% ispitanika.

Glavna uloga AC IOTN jeste da se oceni u kojoj meri je izgled lica narušen ortodontskom nepravilnošću. Tako su, u pogledu ovog parametra, Manzanera i saradnici [15] kod dvanaestogodišnjaka u Španiji dali sledeće ocene: 1-4 mala ili nikakva potreba za terapijom - 85,4\% dece, 5-7 srednja potreba - 10,2\% dece, i $8-10$ velika potreba $-4,4 \%$ ispitanika. Slične ocene $u$ odnosu na estetiku dali su i Suam i saradnici [14] u okviru svog istraživanja među decom uzrasta 9-12 godina u Francuskoj. Tako je u njihovom istraživanju $75 \%$ dece dobilo ocene $1-4,18 \%$ ocene $5-7$, a $7 \%$ ocene $8-10$.

U Italiji su Nobile (Nobile) i saradnici [25] izveli istraživanje među decom uzrasta 11-14 godina u kojem su poredili AC ocene ispitivača i ispitivane dece, slično kao u našem istraživanju. Tako su došli do sledećih rezultata: ocene 1-4 ispitivač je dao u 77,8\% slučajeva, a ispitanici u 91,5\%, ocene 5-7 u 13,6\% slučajeva, a deca u $5,4 \%$, a ocene $8-10$ kod $8,6 \%$ ispitanika, a deca kod 3,2\%. Na osnovu ovih rezultata zaključili su da je stručno stomatološko mišljenje znatno kritičnije od mišljenja ispitanika u vezi s narušenošću estetike lica ortodontskom nepravilnošću. 
Do istog zaključka su došli i Lindrer-Arson (Lindrer-Arson) [11] među ispitanicima u Švedskoj i Abdulah i Rok [23] među ispitanicima u Maleziji.

Taušeova i saradnici [16] su u okviru svoga istraživanja među decom uzrasta od šest do osam godina u Nemačkoj došli do značajno drugačijih rezultata nego u prethodnim istraživanjima. Ona na sledeći način ocenjuje estetiku u pogledu zastupljene ortodontske nepravilnosti: ocene 1-4 kod 34\%, ocene 5-7 kod $44,5 \%$ i ocene $8-10$ kod 21,5\% ispitanika. Holms (Holmes) [26], Krauter (Crowther) i saradnici [27] i Suam i saradnici [14] smatraju da AC ne treba primenjivati kod dece s mešovitom denticijom, jer se veoma često neke tzv. privremene ortodontske nepravilnosti koriguju vremenom, tokom perioda najvećeg rasta i razvoja i prekidanjem loših navika (sisanje prsta, tiskanje jezika i disanje na usta). Upravo iz ovih razloga se javljaju visoke vrednosti ocena za potrebu za ortodontskom terapijom, ako se $\mathrm{AC}$ primenjuje kod dece $s$ mešovitom denticijom.

\section{ZAKLJUČAK}

Kod dece u Republici Srpskoj zabeležena je velika rasprostranjenost ortodontskih nepravilnosti. Više od četvrtine ispitivane populacije ima veoma veliku i hitnu potrebu za ortodontskim lečenjem kojim bi se sprečilo dalje narušavanje zdravlja njihovog stomatognatog sistema. Izvođenje periodičnih epidemioloških istraživanja pomoću ortodontskih indeksa, kao i njihovo uvođenje u kliničku praksu, bilo bi veoma značajno za planiranje i primenu mera prevencije, kao i za organizovanje zdravstvene stomatološke službe. 